\title{
Bird Notes From the Files
}

\author{
By MARGARET BELCHER, Regina, Sask.
}

From the first number published in 1942, the Blue Jay has served the cause of bird study in many ways. It sponsors an annual Christmas bird count, which has now recorded 73 winter species in Saskachewan; it takes part in such projects as the Museum's Whooping Crane survey and the continent-wide Co-operative Study of Migration; and it invites data on Saskatchewan species for the files of the. Saskatchewan Natural History Society.

Of particular interest in the records sent to the Blue Jay are those of the occurrence of a rare or new species, or of the increase in numbers and the extension of range of species already established. A review of the files of the Blue Jay provides the following bird notes of special interest.

1. Lazuli Bunting, nesting in the garden of Arthur Ward of Burnham in 1942. Rare visitor from West.

2. Buff-breasted Sandpipers, rarely observed migrants across the prairies, noted on May 22, 1943, by Francis Roy of Tullis.

3. Steller's Jay seen at Yorkton, out of its usual western range, by Miss Pauline Summers, 1944.

4. Solitary Sandpiper, nesting record obtained by C. Stuart Francis of Torch River - best Blue Jay record for 1944. First specimen, apparently, to be taken in downy plumage collected by Farley Mowat, near Dundurn, May, 1946.

5. Bullock's Oriole - pair banded by Arthur Ward, Burnham, 1944. Rare visitors.

6. Tule Goose reported as frequently stopping over in migration at Little Manitou Lake, by A. J. Matheson, Neilburg (fall, 1944). First report for the province of this goose, the breeding grounds of which were discovered in the far north in 1941 (an ornithological highlight of the year).

7. Marsh Hawk nesting over water (on a platform of bulrushes) reported by Stuart Houston, May 29, 1946.

8. Mockingbird, rare straggler in Saskatchewan, reported at home of Charles F. Holmes, Dollard, July 6 to 16, 1946.

9. Waxwings (Cedar and Bohemian) - one of each species taken from a mixed flock near Nipawin by Dr. Olin Pettingill of Northfield, Minnesota, June 2, 1946. Mixed flocks of these two species rare.

10. Wilson's Phalarope - a northern nesting record apparently established June 1, 1947, nine miles N.W. of Love Saskatchewan - Dr. Lawrence Walkinshaw, M. G. Street, Billy and Walter Matthews.

11. Pacific Loon shot by Dr. C. Dixon near Kronau, 1947. First Provincial Museum record.

12. Varied Thrush banded by Arthur Ward at Burnham, September 27, 1949.

13. Connecticut Warbler banded by M. G. Street, June 12, 1950, the first record for Nipawin.

14. Yellow-throated Vireo taken at Madge Lake in 1951 by F. W. Lahrman, first Provincial Museum record.

15. Trumpeter Swan nesting in the Cypress Hills, 1953. First Museum nesting record. (U.S.A. population in 1953 was 577).

16. Yellow-breasted Chat, nesting at Fort Qu'Appelle, June 1953. (E. M. Callin).

The Blue Jay files also show the extension of range of species already established in the province. Starlings were first seen by M. G. Street at Nipawin in 1943, by H. M. Rayner at Ituna, 1951, and by Arthur Ward at Burnham 1947. Stuart Francis' report of a Brown Thrasher at Torch River, 1944, and reports of the Lark Sparrow at Lumsden Beach (Dick Bird) and 
in a nesting colony near Fort Qu'Appelle (E. M. Callin) indicate a northward extension of the range of these two species. Current observations supplement historical records in showing that the Magpie population has its ups and downs. Similarly, the Lark Bunting (abundant, for example, at Hawarden in 1950 for the first time since 1937) and the Bobolink (for example, rarely seen now at Sheho where once common) illustrate fluctuating bird populations.

One of the most valuable lists published by the Blue Jay (Vol. 1, No. 3) is Laurence B. Potter's Saskatchewan Bird Records made since the publication of Mitchell's Catalogue of Saskatchewan Birds in 1924. There have also appeared reviews of local lists that begin to supply a regional picture of bird life in the province; namely Stuart Houston's Birds of the Yorkton District, Maurice Street's List of the Birds of Nipawin, Saskatchewan, and the Hoopers' Preliminary List of the Birds of the Somme District. Contributions like the ones mentioned in this report have won the Blue Jay congratulations from such famous ornithologists as J. J. Hickey, author of A Guide to Bird Watching, and P. A. Taverner, well-known author of Birds of Canada.

\section{Recollections of a Night's Rest by the Slough}

By J. H. Grant, Harlan, Sask.

All the long, hot day we travelled in the teeth of a chinook that sent Tumble Weeds bounding over the searing plain and whipped grass tops and weed seeds into our blistering faces - and at evening, arrived at a tiny lake on the edge of the scrubland.

The red sun sank behind a hill and down with it went the wind. Air, cool, soothing and laden with the smell of water crept out from the slough which mirrored dark-green clumps of choke-cherry bush and one patch of crimson sky. A pair of muskrats swam leisurely, leaving in their wake twin "v's" of tiny ripples. A Robin sang from a Silver-berry bush, his inimitable liquid notes mingling with the murmur of the streamlet that fed the pond. From her nest on a Cottonwood stump, a Mourning Dove crooned her plaintive lay, and from somewhere in the range lands beyond, faint and far away came the lowing of cattle.

As dusk settled, the oxen, fullfed on the lush grasses of the lake shore, lay down by the wagon, drawing deep contented breaths and ruminating peacefully. We lay on the warm sand; the fresh vapor-laden air balm to our wind-chafed lips and nostrils, and the mellow gurgling call of the Bittern lulling us to rest.

\section{STOP! Don't Shoot That Bird!}

\section{By Donald Hooper, Somme, Sask.}

Too often a hawk or owl lands in a tree near a farmyard, and the farmer rushes out with a gun and shoots the bird, not stopping to see if it is a friend or foe. We must remember that, as well as poultry in the yard, there are often many rats and mice around the barn, feed corrals and sheaf stacks.

In the winter time the Prairie and Varying Hare feed around the barnyards at night attracting Great Horned Owls. These owls are generally shot by the farmers. It would be much better to shoot near the bird and scare it away if it seems that the chickens are in danger.

This spring, a Great Horned Owl came to our yard and perched on the barn to watch for hares and rats. This bird must have had young ones to feed, for he came day and night for about a week. Sometimes during the day he would sit in the straw near the ruins of an old log barn. There the owl would watch by the hour for rats. The hen house was nearby and the yard was full of poultry but the owl didn't pay any attention to them.

I think that the Great Horned Owl should be protected more. In our district they are becoming scarcer because so many are shot and nests are destroyed. 